\title{
HUMOR STYLES AND COMMUNICATION IN RELATIONSHIPS
}

\section{Abstract}

https://orcid.org/0000-0001-7303-4445

Effective communication in a relationship depends on the styles and strategies used by the spouses. The strategies used by them can foster mutual support, depreciate the partner, or be an indication of commitment (Kazimierczak, Plopa, 2006). Studies of marital relations show that an important aspect that develops bonds and relationship satisfaction is the sense of humor (Cann \& Calhoun, 1997; Saroglou et al., 2010). Researchers dealing with the sense of humor differentiate between four basic styles of humor. The affiliative and self-enhancing styles are regarded as adaptive, while the aggressive and selfdefeating styles are regarded as non-adaptive (Martin et al., 2003). The purpose of the studies is to determine whether there is a relationship between the spouses' humor and communication styles. Another question to be answered is whether there is a relationship between the humor styles and the perception of the partner's communication style in a relationship. It has been concluded that adaptive humor styles correlate with styles based on mutual support and commitment in a relationship. The selfdefeating style, on the other hand, shows relationships with a style that depreciates the partners. No relations have been noted between a specific humor style and the perception of partner's communication style.

Keywords: marriage, communication, humor, humor styles

\section{Introduction}

Communicating is the concept derived from a Latin word communicare which means being in a relation [relationship] with, participating in, banding together (Goban-Klas, 2009). Morreale et al. (2011) distinguish between four models of communication, in which communication is understood as: the transfer of information, creation of shared meaning, persuasion or building the community.

In accordance with the transfer model, the communication process is of one-way character, from a sender to a receiver. This model does not take account of feedback, it emphasizes, however, the effectiveness of the message and accomplishment of the set goal.

The creation of the shared meaning model, on the other hand, assumes that the main purpose of the communication process is mutual understanding between the participants, which is possible in case of feedback between the sender and the receiver. The participants want their intentions to be understood, thus they exchange the role of the sender and the role of the receiver (interaction model), or they even play the role of the sender and the role of the receiver at the same time (transactional model).

The persuasive model focuses on the measures used by the sender in order to effectively impact the recipient and thus accomplish their own intentions.

Another model involves understanding communication as community building. It is close to the transactional model of creating the shared meaning, the difference being that it emphasizes the effects of joint actions and joint accomplishment of the desired goals. Usefulness of specific models depends on the situation in which the communication takes place, due to the fact that effectiveness of a given model depends on the situation.

The concept of communication is linked to the concept of communication competence. The former is a phenomenon relating to interpersonal reality, while the latter describes an intrapsychic phenomenon, a certain individual feature of interaction participants. The concept of communication competence was introduced by Hymes who, unlike Chomsky, believed that linguistic behaviors depend not only on grammar, but also on the roles performed by language users in social groups and on the situations (Kurcz, 2000). Communication competence is an ability to use verbal/nonverbal behavior to accomplish the preferred goals in a manner that is appropriate to the context and effective (cf. Morreale et al. 2011). Thus, it describes the degree of effectiveness and appropriateness of communication behaviors to 
the situation. Evaluation of a given person's competence, according to Morreale et al. (2007), applies to: clarity, applicability and effectiveness. Clear utterances are those that clearly reflect the intentions of the sender and are understandable to the receiver.

Applicability means a form of communication that is adequate to the context, which can be achieved through compliance with specific rules functioning in the cultures, communities, groups and permanent relationships. Such rules are used in specific situations so that a given person is not exposed to sanctions. Effectiveness defines communication that ensures accomplishment of a specific result, i.e. communication that is functional and allows for the fulfillment of certain tasks and goals.

Effective communication in a relationship is conditional on individually built styles and strategies of communication between the spouses. The communication style relates to individual predispositions that determine the shape and character of the communication process with another person that comprises the verbal and nonverbal manner of responding to signals specifying how the content should be understood, interpreted and selected Morreale et al. (2011).

The literature presents a number of classifications of communication styles in couples. Hawkins, Weisberg, Ray (1980 after: Ryś, 1999) have differentiated between four basic communication styles. Their division is based on the degree of openness and type of communication.

- The features of the first of these styles, namely the fully open communication style based on partnership, include listening to the partner, ability to express in a direct manner the feelings toward the partner, am inclination to inform the partner of the feelings evoked by his/her behavior. People who have this communication style as dominant do not hide from the partner their real intentions, can listen and focus on the behavior and the content uttered by their interlocutor. They neither impose their opinion on the partner nor subordinate their opinions to him/her.

- The conventional style, on the other hand, is characterized by low level of openness of the partners to reveal their views, feelings or thoughts. People who have this style avoid direct conversations about problems or direct confrontation during the conversation, and at the same time allow for a distance in fear of being unmasked and discredited, which is related to the fear of exposing oneself.

- The controlling style consists in one partner's desire to subordinate the other partner. This style is also expressly characterized by lack of openness in articulating one's intentions.

- The speculative style, on the other hand, is characterized by indirect manner of articulating one's views, thoughts and feelings.

A different division has been proposed by $\mathrm{E}$. Trzebińska (1981 after: Zalewska, 2008) who defines the type of the relationship between interlocutors through such communication styles as egocentric, allocentric, and based on partnership. The egocentric style is characterized by an assumption that one's own position is higher than the position of the partner, the allocentric style is expressed in assigning a higher position to the partner, while the style based on partnership is characterized by assigning equal positions to oneself and the partner.

Kazimerczak and Plopa (2006) were also interested in analyzing communication in relationships. They differentiated between three significant areas of communication between the spouses. They included: supportive communication, communication depreciating the partner, and committed communication. Supportive communication is characterized by taking care of the partner, showing interest in their problems and needs and helping them in solving their problems. Communication that depreciates the partner involves emphasizing one's own dominance over the partner, launching aggressive behaviors and controlling their actions. Committed communication, on the other hand, is expressed through taking actions aimed at building the atmosphere of intimacy and understanding in a relationship, stressing the partner's uniqueness and attempting to constructively resolve conflicts.

No matter which typology is adopted, it should be noted that each person usually presents a specific communication style. Some people tend to directly communicate their thoughts and feelings (Tannen, 1987), while others express them in an indirect way and do not want to reveal their real intentions.

Researchers dealing with humor emphasize the existence of various styles of behavior associated with the use of humorous messages. Martin and his co-researchers (2003), who define 
humor styles as, preferred by an individual, typical ways of using humor, including also the building of specific utterances, have differentiated between four humor styles. They include the affiliative, self-enhancing, aggressive and self-defeating humor styles.

The authors have defined affiliative humor as adaptive, focused on other persons, and characterized by a tendency to build positive relationships with others. This style usually builds a good atmosphere, expresses full acceptance for other people, is characterized by kindness and a tendency to avoid conflicts.

Self-enhancing humor, which is also referred to as adaptive, is focused on oneself. It defines a tendency to humorous attitude to life with a clear ability to distance yourself from everyday problems, and to cope with stress-inducing and frightening situations (Kuiper, Martin \& Olinger, 1993).

According to the authors, aggressive humor is a non-adaptive style. It is mainly focused on other people, but it aims at emphasizing one's own value, demonstrating superiority over others, sometimes even humiliating others, or depreciating their value. Typical forms of such humor include: sarcasm, teasing, ridicule and humiliation (Zillman, 1983).

Although self-defeating humor is a nonadaptive style as well, it is focused on oneself. It usually uses oneself and one's own deficiencies and limitations as a potential source of humor in order to win the acceptance of others. Being of an integrative character, it is used to please others at one's own expense (Martin et al., 2003).

The use of humorous utterances requires communication competence which includes: joke competence and humor competence (Carrell, 2000). The concept of joke competence (humorous text) is necessary to categorize a given text as a joke (humorous text). This does not mean, however, that it is regarded as funny. It is the domain of humor competence. Carrell defines it as a dynamic construct which is formed by individual, random events, often dependent on the situation in which a joke is presented.

Having the joke and humor competences is important for interpersonal relationships, as they are an indication of having a sense of humor. Numerous studies indicate that we seek people who have a sense of humor, we simply try to win their favor and want to be found attractive by them.
This is associated with benefits that we can gain from contacts with such people. They give us pleasure derived from laughter, while at the same time, thanks to the way they behave and their ability to look at oneself from a distance, they are less likely to take offence and do not burden us with negative emotions (Cook \& Rice, 2003). Another important thing is when somebody else shares our sense of humor and laughs at our jokes. Such a person is then perceived as more attractive interpersonally (Cann et al., 1997).

Because of a specific character of humor, its presence in interpersonal relations is conducive to building the sense of intimacy and strengthening the relations (Fraley \& Aron, 2004). Coser (1960: after Kuipers, 1980) points out that humor or laughter aroused by humorous messages reduce social distance and make the relations more open. It is an effective way of forming social bonds, even in situations which initially are not conducive to intimacy.

Researchers dealing with humor emphasize that it is not only jokes, understanding, creating and telling them, but also a type of specific interpersonal interaction based on ambiguity (Kane, 1977; Long, Graesser, 1988; Martineau, 1972; Norrick, 1993). A specific character of humorous message stems from the use of ambiguity and contradiction (Raskin, 1985), and as a result, certain messages may be interpreted in interpersonal relations in two different ways, which in difficult, conflict situations allows for example to find an honourable solution and save face (cf. Goffman, 1997). As pointed out by Erving Goffman (1977), people are generally strongly motivated to avoid communication when there is a likelihood of confrontation. Humor can be a useful strategy to deal with such type of situations (Zajdman, 1995), although this is not always done consciously or treated as a strategic goal.

Humor also performs an important role in inter-partner relations. It was observed that partners who have the sense of humor are perceived as more attractive (Cann et al., 1997) and trustworthy by their female partners, though less intelligent (Bresler, Balshine, 2006 after: Saroglou et al., 2010). Besides, it allows us to draw conclusions about other positive qualities of a potential partner. In other studies it was found that partners who jointly experience funny situations during their first meetings develop a greater sense of intimacy (Haas \& Stafford, 2005). In addition, 
studies show that similarity in terms of sense of humor is associated with the perception of higher attractiveness of partners and willingness to merry quickly. In other studies, however, no correlation was observed between similarities in appreciating a given type of humor and marital satisfaction. It was only determined that the spouses share similarities in what they find to be humorous (Priest \& Thein, 2003, after: Cann et al., 2010). This may suggest that at the initial stages of a relationship, humor plays an important role and determines the attractiveness of the partners, however, when the marital relationship develops, the relation between humor and marital satisfaction becomes more complex. It consists not only in appreciating the same humorous stimuli, but is also associated with partners' mutual reactions to themselves. In conflict situations, it allows for releasing the tension, though not every style of humor is conducive thereto. Hostile humor escalates the conflict even further (Bippus, 2003). Cann et al. (2011) believe that the way the partner's sense of humor is perceived may be more important for developing the relationship between the partners than the way one's own sense of humor is perceived. Arnie Cann et al. (2011) tried to determine whether satisfaction with being in a relationship depends on similarities between our own sense of humor and the perception of our partner's sense of humor. The studies conducted showed that similarities between the style of humor and marital satisfaction are of little significance. The best indicator of relationship satisfaction was the perception of a certain humor style in a partner.

In numerous studies into the importance of sense of humor attempts were made to determine whether partners appreciate the same humorous stimuli and whether they generally have a sense of humor. However, due to the development of studies of humor, the current conducted studies of humor in partner relationships take into account both the positive and negative aspects of humor in interpersonal relations.

The studies of Vassilisa Saroglou et al. (2010) focused on finding a relationship between humor styles and marital satisfaction. The conducted studies show that adaptive humor styles, i.e. the affiliative and self-enhancing ones, particularly in men, are associated with higher level of relationship satisfaction. Non-adaptive humor styles (the aggressive and self-defeating ones), on the other hand, are associated with low level of relationship satisfaction and provide basis to draw conclusions about its breakdown (Saroglou et al., 2010). Researchers observed that the use of selfenhancing humor by married men is an indicator of high marital satisfaction in both husbands and wives. Men, on the other hand, showed higher marital satisfaction when women demonstrated self-defeating humor. As pointed out by the authors, this is not entirely surprising if one takes into account the traditional asymmetry in marriage. Husbands may like such style as it does not explicitly express asymmetry. The fact that men's but not women's self-enhancing humor plays a role in positive assessment of a relationship by both partners can be explained through reference to gender stereotypes. It was found that men more often than women use various humor styles, with the exception of the self-defeating one. Thus, married men contribute to marital satisfaction by using adaptive humor styles. Soroglou et al. (2010) also make an assumption that marital satisfaction may be related to similarity in humor styles between the spouses. No similarities in the use of adaptive humor styles were observed. The use by men of one of these humor styles, namely the self-enhancing style, may contribute to differences in both partners' satisfaction. Besides, it was observed that in married couples who have survived an average period of 20 years of marriage, the relationship between humor styles and marital satisfaction may differ when compared to groups of newly married or engaged couples (Driver, Gottman, 2004; Campbell et al., 2008 after: Soroglou, 2010). It should be emphasized that similarity relates rather to negative than positive humor styles.

Sara Caird and Rod Martin (2014) formulated a hypothesis that humor styles show a relationship with wellbeing and this may have an impact on relationship satisfaction. They concluded that affiliative humor allows for a most accurate prediction of relationship satisfaction. They observed that on the days when people joked and laughed with their partners more often than usually, they also assessed their relationship as a more satisfactory. On the other hand - which was found surprising - regardless of the days, no relationship was observed between aggressive humor and relationship satisfaction or dissatisfaction. On the days when the participants used self-enhancing humor more often than 
usually, their relationship satisfaction increased. When the participants used self-defeating humor, their relationship satisfaction decreased compared to a typical level. Researchers make an assumption that on the days when people demonstrate a more optimistic and positive attitude to life, there appear more adaptive humor styles. In this frame of mind, an attitude can be developed to use humor that allows to cope with difficult situations, which has an impact on a positive assessment of a relationship. It was concluded that occasional use by the participants of self-defeating humor does not need to be a problem, but if it is a common pattern of humor used in a relationship, then it may reduce the sense of satisfaction.

Besides, the subject of analyses were the relationships between humor styles and the level of satisfaction as a sum of a number of measurements. It was shown that there is a relationship between affiliative humor and relationship satisfaction. Some relationships were also observed between aggressive style and lack of relationship satisfaction. This suggests that the general use of aggressive humor is more important for the existence or lack of relationship satisfaction than occasional one-day use thereof relating to the mood. Negative relationships were observed between occasional, depended on the day use of self-defeating humor and relationship satisfaction among people who usually show high level of use of such humor. According to Sara Craid and Rod Martin (2010), persons showing low level of relationship satisfaction may use self-defeating humor as a way of gaining approval. Another possibility is that an increase in the use of selfdefeating humor may contribute to low assessment of their relation. Researchers emphasize the need to verify how relationship satisfaction is influenced by an impact of one partner's style on the other partner. There are certain suggestions that the use of a specific humor style by a given person may be to a larger extent associated with their partner's relationship satisfaction than with the person's own satisfaction.

\section{Methodology}

The purpose of the conducted studies is to determine whether specific humor styles in a relationship are accompanied by a different communication style. Observations made by Martin (Martin et al., 2003) show that humor styles may be of adaptive as well as non-adaptive character. On the one hand, they allow to maintain our own self-esteem, regulate negative emotions and influence positive relations with others, on the other hand, however, the use of humor may be associated with depreciating oneself in order to gain approval of others and expressing aggression towards others.

It can be assumed, therefore, that adaptive humor styles (the affiliative and self-enhancing ones) will show a relationship with communication styles focused on support for the partner, committing to relations with the partner (both in a situation when the subject of assessment is the communication style of a person demonstrating a given humor style and in a situation when the subject of assessment is the communication style of a partner).

Furthermore, non-adaptive humor styles will be accompanied by the communication style based on depreciating the partner (both in a situation of assessing one's own and the partner's communication style).

Thus, the following research hypotheses have been formulated in this study:

1. There exist a relationship between humor styles and the perception of one's own communication style in a relationship, whereby adaptive humor styles (the affiliative and selfenhancing ones) are accompanied by the communication style that supports the partner and shows commitment. Non-adaptive communication styles, on the other hand, will be accompanied by a depreciating communication style.

2. There exists a relationship between humor styles and the perception of the partner's communication styles in a relationship, whereby adaptive humor styles, namely the affiliative and self-enhancing ones, will be accompanied by the communication style that supports the partner and shows commitment. Non-adaptive communication styles, on the other hand, will be accompanied by a depreciating communication style.

What is more, a question is posed whether similar dependencies will be found when the group of women and the group of men are analyzed separately. The hypotheses formulated are similar to those presented above.

3. In the group of women and in the group of men, there exist a relationship between humor styles and the perception of one's own communication style in a relationship, whereby the adaptive humor styles, namely the affiliative and self-enhancing ones, will be accompanied by 
a communication style that supports the partner and shows commitment. Non-adaptive communication styles, on the other hand, will be accompanied by a depreciating communication style.

4. In the group of women and in the group of men there exist a relationship between humor styles and the perception of the partner's communication style in a relationship, whereby the adaptive humor styles, namely the affiliative and self-enhancing ones, will be accompanied by a communication style that supports the partner and shows commitment. Non-adaptive communication styles, on the other hand, will be accompanied by a depreciating communication style.

The following two questionnaires have been used in order to answer the posed research questions and verify the formulated hypothesis: The Humor Styles Questionnaire (HSQ) developed by Rod Martin, Patricia Puhlik-Doris, Gwen Larsen and Kelly Weir and the Communication in Marriage Questionnaire (KKM) developed by Maria Kaźmierczak and Mieczysaw Plopa.

The Humor Styles Questionnaire (HSQ) by Rod Martin, Patricia Puhlik-Doris, Gwen Larsen and Kelly Weir is a method that relates to the four previously discussed humor styles, namely the affiliative, self-enhancing, self-defeating and aggressive ones. An experimental version of this questionnaire, developed by Anna Radomska (2007), has been used for this study.

The questionnaire comprises four scales that measure four humor styles. It consists of 32 questions.

Another questionnaire used for the study is the Communication in Marriage Questionnaire that consists of three dimensions:

- Support - this dimension relates to showing respect to the partner by appreciating their efforts, demonstrating interest in their problems and needs, and active participation in the problem-solving process.
- Commitment - means an ability to build the atmosphere of mutual understanding and intimacy in a relationship by showing each other feelings, emphasizing the uniqueness and importance of our partner, diversifying every-day routine, and preventing conflicts in a relationship.

- Depreciation - means showing aggression towards the partner, an intention to dominate the partner and control their actions, showing no respect to the partner's dignity.

The study has been conducted among 44 married couples, i.e. 88 people. Average length of marriage in the studied group is 16.5 years, the group includes persons whose marriage has lasted from 2 to 38 years. All couples participating in the study have children, from 1 to 7 . The study has been conducted anonymously.

\section{Results}

The statistical analysis has been carried out with the use of SPPS 18 statistical software package. The Pearson correlation test has been used.

The achieved results show that affiliative humor shows a relationship with an ability to demonstrate commitment in a relationship. What is more, it has been concluded that self-enhancing humor style shows a relationship with the style focused on providing support.

It has been also observed that depreciating the partner (the depreciating style) is accompanied by the use of self-defeating humor. The studies have shown no correlation between aggressive humor style and any of the communication styles.

Analysis of correlation between the humor style and the perception of partner's communication style has shown no statistically significant relationship either (Table 2).

Such relationships occur when gender is taken into account (Table 3). Men more often use self-enhancing humor if they observe in their female partner a tendency toward behavior that indicates building a good atmosphere in a relationship, intimacy in the relations (styles based on commitment). 
Table 1

Correlation between the humor style and one's own communication style in a relationship

\begin{tabular}{|c|c|c|c|c|c|}
\hline Humor styles & & $\begin{array}{c}\text { Number of } \\
\text { persons }\end{array}$ & $\begin{array}{c}\text { Support } \\
\text { (one's own } \\
\text { behavior) }\end{array}$ & $\begin{array}{c}\text { Commitment } \\
\text { (one's own } \\
\text { behavior) } \\
\end{array}$ & $\begin{array}{c}\text { Depreciation } \\
\text { (one's own } \\
\text { behavior) } \\
\end{array}$ \\
\hline \multirow[t]{2}{*}{ Affiliative humor } & $\begin{array}{l}\text { Pearson } \\
\text { correlation }\end{array}$ & 88 & 0.08 & $0.22(*)$ & -0.01 \\
\hline & $\begin{array}{l}\text { Significance } \\
\text { level }\end{array}$ & 88 & 0.42 & 0.03 & 0.88 \\
\hline \multirow[t]{2}{*}{$\begin{array}{l}\text { Self-enhancing } \\
\text { humor }\end{array}$} & $\begin{array}{l}\text { Pearson } \\
\text { correlation }\end{array}$ & 88 & $0.23(*)$ & 0.15 & 0.00 \\
\hline & $\begin{array}{l}\text { Significance } \\
\text { level }\end{array}$ & 88 & 0.02 & 0.15 & 0.99 \\
\hline \multirow[t]{2}{*}{$\begin{array}{l}\text { Self-defeating } \\
\text { humor }\end{array}$} & $\begin{array}{l}\text { Pearson } \\
\text { correlation }\end{array}$ & 88 & 0.09 & -0.06 & $0.27(*)$ \\
\hline & $\begin{array}{l}\text { Significance } \\
\text { level }\end{array}$ & 88 & 0.37 & 0.56 & 0.01 \\
\hline \multirow[t]{2}{*}{$\begin{array}{l}\text { Aggressive } \\
\text { humor }\end{array}$} & $\begin{array}{l}\text { Pearson } \\
\text { correlation }\end{array}$ & 88 & -0.07 & 0.07 & 0.09 \\
\hline & $\begin{array}{l}\text { Significance } \\
\text { level }\end{array}$ & 88 & 0.46 & 0.49 & 0.37 \\
\hline
\end{tabular}

Table 2

Correlation between the humor style and the perception of partner's communication style

\begin{tabular}{|c|c|c|c|c|c|}
\hline Humor styles & Number & $\begin{array}{c}\text { Support } \\
\text { (partner's } \\
\text { behavior) }\end{array}$ & $\begin{array}{c}\text { Commitment } \\
\text { (partner's } \\
\text { behavior) }\end{array}$ & $\begin{array}{c}\text { Depreciation } \\
\text { (partner's } \\
\text { behavior) }\end{array}$ \\
\hline \multirow{2}{*}{ Affiliative humor } & $\begin{array}{c}\text { Pearson } \\
\text { correlation }\end{array}$ & 88 & -0.05 & 0.03 & 0.12 \\
\cline { 2 - 6 } & $\begin{array}{c}\text { Significance } \\
\text { level }\end{array}$ & 88 & 0.62 & 0.74 & 0.26 \\
\hline Self-enhancing humor & $\begin{array}{c}\text { Pearson } \\
\text { correlation }\end{array}$ & 88 & 0.00 & 0.11 & 0.14 \\
\cline { 2 - 6 } & $\begin{array}{c}\text { Significance } \\
\text { level }\end{array}$ & 88 & 0.99 & 0.27 & 0.18 \\
\hline \multirow{2}{*}{ Self-defeating humor } & $\begin{array}{c}\text { Pearson } \\
\text { correlation }\end{array}$ & 88 & -0.05 & 0.09 & 0.16 \\
\cline { 2 - 6 } & $\begin{array}{c}\text { Significance } \\
\text { level }\end{array}$ & 88 & 0.64 & 0.37 & 0.14 \\
\hline \multirow{2}{*}{$\begin{array}{c}\text { Aggressive } \\
\text { humor }\end{array}$} & $\begin{array}{c}\text { Pearson } \\
\text { correlation }\end{array}$ & 88 & 0.03 & 0.09 & 0.37 \\
\cline { 2 - 6 } & $\begin{array}{c}\text { Significance } \\
\text { level }\end{array}$ & 88 & 0.72 & 0.37 \\
\hline
\end{tabular}

A correlation has been also found between aggressive humor and the perception of a female partner as supportive (Table 3.) (see next page below). 
Correlation between husbands' humor style and the perception of wives' communication style

\begin{tabular}{|l|l|c|c|c|c|}
\hline Humor styles & & $\begin{array}{c}\text { Number of } \\
\text { persons }\end{array}$ & $\begin{array}{c}\text { Support } \\
\text { (partner's } \\
\text { behavior) }\end{array}$ & $\begin{array}{c}\text { Commitment } \\
\text { (partner's } \\
\text { behavior) }\end{array}$ & $\begin{array}{c}\text { Depreciation } \\
\text { (partner's } \\
\text { behavior) }\end{array}$ \\
\hline Affiliative humor & $\begin{array}{l}\text { Pearson } \\
\text { correlation }\end{array}$ & 44 & 0.09 & 0.22 & -0.00 \\
\cline { 2 - 6 } & $\begin{array}{l}\text { Significance } \\
\text { level }\end{array}$ & 44 & 0.52 & 0.14 & 0.98 \\
\hline Self-enhancing humour & $\begin{array}{l}\text { Pearson } \\
\text { correlation }\end{array}$ & 44 & 0.21 & $0.34\left(^{*}\right)$ & -0.14 \\
\cline { 2 - 6 } & $\begin{array}{l}\text { Significance } \\
\text { level }\end{array}$ & 44 & 0.16 & 0.02 & 0.33 \\
\hline Self-defeating humor & $\begin{array}{l}\text { Pearson } \\
\text { correlation }\end{array}$ & 44 & 0.17 & 0.21 & -0.25 \\
\cline { 2 - 6 } & $\begin{array}{l}\text { Significance } \\
\text { level }\end{array}$ & 44 & 0.25 & 0.17 & 0.10 \\
\hline $\begin{array}{l}\text { Aggressive } \\
\text { humor }\end{array}$ & $\begin{array}{l}\text { Pearson } \\
\text { correlation }\end{array}$ & 44 & $0.30\left(^{*}\right)$ & 0.26 & 0.10 \\
\cline { 2 - 6 } & $\begin{array}{l}\text { Significance } \\
\text { level }\end{array}$ & 44 & 0.04 & 0.08 & 0.50 \\
\hline
\end{tabular}

No statistically significant relationships between the humor style and their own perception of communication style have been noted in the husbands' group (Table 4).

Table 4

Correlations between husbands' humor style and their communication style

\begin{tabular}{|l|l|c|c|c|c|}
\hline \multicolumn{1}{|c|}{ Humor styles } & & $\begin{array}{c}\text { Number of } \\
\text { persons }\end{array}$ & $\begin{array}{c}\text { Support } \\
\text { (one's own } \\
\text { behavior) }\end{array}$ & $\begin{array}{c}\text { Commitment } \\
\text { (one's own } \\
\text { behavior) }\end{array}$ & $\begin{array}{c}\text { Depreciation } \\
\text { (one's own } \\
\text { behavior) }\end{array}$ \\
\hline Affiliative humor & $\begin{array}{l}\text { Pearson } \\
\text { correlation }\end{array}$ & 44 & 0.02 & -0.06 & 0.09 \\
\cline { 2 - 6 } & $\begin{array}{l}\text { Significance } \\
\text { level }\end{array}$ & 44 & 0.85 & 0.66 & 0.54 \\
\hline Self-enhancing humour & $\begin{array}{l}\text { Pearson } \\
\text { correlation }\end{array}$ & 44 & 0.13 & 0.07 & -0.11 \\
\cline { 2 - 6 } & $\begin{array}{l}\text { Significance } \\
\text { level }\end{array}$ & 44 & 0.37 & 0.62 & 0.45 \\
\hline \multirow{2}{*}{ Self-defeating humor } & $\begin{array}{l}\text { Pearson } \\
\text { correlation }\end{array}$ & 44 & -0.10 & -0.05 & 0.08 \\
\cline { 2 - 6 } & $\begin{array}{l}\text { Significance } \\
\text { level }\end{array}$ & 44 & 0.49 & 0.74 & 0.57 \\
\hline $\begin{array}{l}\text { Aggressive } \\
\text { humor }\end{array}$ & $\begin{array}{l}\text { Pearson } \\
\text { correlation }\end{array}$ & 44 & 0.07 & 0.10 & -0.04 \\
\cline { 2 - 6 } & $\begin{array}{l}\text { Significance } \\
\text { level }\end{array}$ & 4 & 0.64 & 0.48 & 0.76 \\
\hline
\end{tabular}

Analysis of results in the group of women do not show any statistically significant relationships between the humor style presented by them and the perception of men's communication style (Table 5). 
Correlations between wives' humor style and the perception of husbands' communication style

\begin{tabular}{|l|l|c|c|c|c|}
\hline \multicolumn{1}{|c|}{ Humor styles } & & $\begin{array}{c}\text { Number of } \\
\text { persons }\end{array}$ & $\begin{array}{c}\text { Support } \\
\text { (partner's } \\
\text { behavior) }\end{array}$ & $\begin{array}{c}\text { Commitment } \\
\text { (partner's } \\
\text { behavior) }\end{array}$ & $\begin{array}{c}\text { Depreciation } \\
\text { (partner's } \\
\text { behavior) }\end{array}$ \\
\hline Affiliative humor & $\begin{array}{l}\text { Pearson } \\
\text { correlation }\end{array}$ & 44 & -0.16 & -0.11 & 0.23 \\
\cline { 2 - 6 } & $\begin{array}{l}\text { Significance } \\
\text { level }\end{array}$ & 44 & 0.27 & 0.44 & 0.12 \\
\hline Self-enhancing humor & $\begin{array}{l}\text { Pearson } \\
\text { correlation }\end{array}$ & 44 & 0.06 & -0.01 & -0.09 \\
\cline { 2 - 6 } & $\begin{array}{l}\text { Significance } \\
\text { level }\end{array}$ & 44 & 0.69 & -0.01 & -0.96 \\
\hline Self-defeating humor & $\begin{array}{l}\text { Pearson } \\
\text { correlation }\end{array}$ & 44 & 0.05 & -024 & -0.01 \\
\cline { 2 - 6 } & $\begin{array}{l}\text { Significance } \\
\text { level }\end{array}$ & 44 & 0.71 & 0.10 & 0.94 \\
\hline $\begin{array}{l}\text { Aggressive } \\
\text { humor }\end{array}$ & $\begin{array}{l}\text { Pearson } \\
\text { correlation }\end{array}$ & 44 & -0.14 & -0.08 & 0.12 \\
\cline { 2 - 6 } & $\begin{array}{l}\text { Significance } \\
\text { level }\end{array}$ & 4 & 0.33 & 0.58 & 0.41 \\
\hline
\end{tabular}

A relationship has been found between the aggressive humor style and the style depreciating the behavior of the partner, i.e. the style that expresses aggression, intention to control and depreciate the partner (Table 6).

Correlations between wives' humor style and their communication style

\begin{tabular}{|l|l|c|c|c|c|}
\hline \multicolumn{1}{|c|}{ Humor styles } & \multicolumn{1}{|c|}{$\begin{array}{c}\text { Number } \\
\text { of persons }\end{array}$} & $\begin{array}{c}\text { Support } \\
\text { (one's own } \\
\text { behavior) }\end{array}$ & $\begin{array}{c}\text { Commitment } \\
\text { (one's own } \\
\text { behavior) }\end{array}$ & $\begin{array}{c}\text { Depreciation (one's } \\
\text { own behavior) }\end{array}$ \\
\hline Affiliative humor & $\begin{array}{l}\text { Pearson } \\
\text { correlation }\end{array}$ & 44 & 0.08 & 0.23 & -0.03 \\
\cline { 2 - 6 } & $\begin{array}{l}\text { Significance } \\
\text { level }\end{array}$ & 44 & 0.60 & 0.12 & 0.84 \\
\hline Self-enhancing humour & $\begin{array}{l}\text { Pearson } \\
\text { correlation }\end{array}$ & 44 & 0.10 & 0.10 & 0.03 \\
\cline { 2 - 6 } & $\begin{array}{l}\text { Significance } \\
\text { level }\end{array}$ & 44 & 0.48 & 0.48 & 0.08 \\
\hline Self-defeating humor & $\begin{array}{l}\text { Pearson } \\
\text { correlation }\end{array}$ & 44 & -0.09 & 0.03 & -0.03 \\
\cline { 2 - 6 } & $\begin{array}{l}\text { Significance } \\
\text { level }\end{array}$ & 44 & 0.56 & 0.81 & 0.83 \\
\hline $\begin{array}{l}\text { Aggressive } \\
\text { humor }\end{array}$ & $\begin{array}{l}\text { Pearson } \\
\text { correlation }\end{array}$ & 44 & -0.21 & -0.04 & 0.37 \\
\cline { 2 - 6 } & $\begin{array}{l}\text { Significance } \\
\text { level }\end{array}$ & 44 & 0.15 & 0.76 & $0.01^{*}$ \\
\hline
\end{tabular}

\section{Discussion}

The studies allow for adopting a hypothesis that there exist a relationship between humor styles and communication styles. It has been observed that adaptive humor styles positively correlate with communication styles based on mutual support and commitment in a relationship.

The use of affiliative humor is conducive to the development of mutual understanding and intimacy in a relationship, it builds good atmosphere and correlates with a tendency to emphasize uniqueness and importance of the partner. Avoiding conflicts in a relationship becomes possible if it is accompanied by affiliative humor characterized by kindness.

Focused on oneself adaptive (selfenhancing) humor, which is characterized by a tendency to adopt a humorous approach toward life and an ability to distance yourself from everyday problems, copying with stress-inducing and threatening situations, shows a relationship 
with providing support to the partner by respecting their efforts, being interested in their problems, and actively participating in the joint problemsolving process. Proving support to the partner serves the purpose of coping with the problems, or at least distancing yourself from them, and because of that this humor style is conducive thereto.

The studies conducted by Saroglou et al. (2010) show that adaptive humor styles, i.e. the affiliative and self-enhancing styles, particularly in men, were associated with higher level of relationship satisfaction. Researchers observed that the use of self-enhancing humor by married men is an indicator of high marital satisfaction in both husbands and wives.

On the other hand, non-adaptive humor styles (the aggressive and self-defeating ones) have correlated with low level of relationship satisfaction and provided basis to draw conclusions about its breakdown.

The results of own studies show that nonadaptive humor styles correspond with communication styles that are unfavorable to a relationship. The observed correlation allows to conclude, however, that the self-defeating humor style is present when we depreciate our partners. The fact of expressing negative, critical comments relating to oneself may be done in order to illustrate how a given person feels treated in a relationship, to implicitly communicate their dissatisfaction. Thanks to this technique, the participants of the study may find it easier than through a directly built message to express their dissatisfaction, grief, and the way they are treated in a relationship.

No relations have been noted between a specific humor style and the perception of partner's communication style. This shows constancy and lack of flexibility in adapting communication styles depending on the perception of the partner's communication style.

Different dependencies have been observed in the group of women and men, which only to some extent confirms the third or the forth hypothesis. The use of self enhancing style is observed in men who notice in their wives the communication style based on providing support, which may be associated with the need to emphasis their strengths, in particular when their wives are committed to a relationship. This may be associated with self-promotion of men. The aggressive humor style is also accompanied by a belief that wives use communication style based on providing support. A suspicion arises that the stereotypical perception of men as those who provide support and are tough makes it more difficult for them to appreciate utterances in which wives attempt to support their husbands. Men may perceive such utterances as expressing a belief about their weakness. They are aware, however, that their wives' intention is positive, and then aggressive humor is a hidden negative response to their wives’ behavior.

\section{Conclusion}

The observations made provide a starting point for questions about the effectiveness of the adopted strategies. Is it really true that the observed correlations between humor styles and communication styles indicate the most optimal communication style with the use of humor? The observed dependencies show that humor, as a communication style with the use of many voices, allows us not only to express the content explicitly, but also to express the content that cannot be expressed openly. The use of humor makes it possible to hide our real intentions, avoid direct confrontation or exposing the other person to critical personal comments. It also makes it possible to hide tendencies toward self-promoting behavior by making references to one's good points under the guise of humor.

As suggested by the researchers, the use of humor in communication between the spouses may have both adaptive and nonadaptive character. This depends on the humor style used to convey the content, but also on the situation. Not always indirectly expressing the content must be the right way of communicating difficult messages, because it may lead to lack of unambiguity of the message, and will thus blur the problem.

Conflict of interest. We state that there is no conflict of scientific interests.

\section{References}

Bippus, A. (2003). Humor motives, qualities and reactions in recalled conflict episodes. Western Journal of Communication 67(4). 413-426.

Bressler, E. R., \& Balshine, S. (2006). The influence of humor on desirability. Evolution and Human Behavior, 27, 29-39.

Campbell, Lorne, Rod Martin \& Jennie Ward. 2008. An observational study of humor use 
while resolving conflict in dating couples. Personal Relationships 15(1). 41-55.

Cann, A., Calhoun, L. G., \& Banks, J. S. (1997). On the role of humor appreciation in interpersonal attraction: It's no joking matter. Humor: International Journal of Humor Research,10(1), 77-89.

Cann, Arnie \& Lawrence G. Calhoun. 2001. Perceived personality associations with differences in sense of humor: Stereotypes of hypothetical others with high or low senses of humor. Humor,13, 1-14.

Carrell, A. (2000). Two Facets of Communicative Competence: Joke Competence and Humor

Competence. In: Gajda, S., Brzozowska, D. (ed.), Świat humoru. Opole: The Department of Polish Philology at the University of Opole (pp. 27-36). Print Shop of the Holy Cross Publishing House (Wydawnictwo Świętego Krzyża) in Opole.

Caird, S, Martin, R. (2014). Relationship-focused humor styles and relationship satisfaction in dating couples: A repeated-measures design. Humor27 (2), 227-247.

Coser, R. L. (1960). Laughter among colleagues: A study of the functions of humor among the staff of a mental hospital. Psychiatry, 23, 81-95.

Cook, K. S., Rice, E. (2003). Social exchange theory. In: J. Delamater (ed.), Handbook of social psychology (pp. 53-76). New York: Plenum.

Driver, J., L., Gottman.J., M. (2004). Daily marital interactions and positive affect during marital conflict among newlywed couples. Family Process, 43, 301-314.

Goban-Klas, T. (2009). Media i komunikowanie masowe. Warszawa: Wydawnictwo Naukowe PWN (Polish Scientific Publishers).

Goffman, E. (1977). Człowiek w teatrze życia codziennego. Warszawa: PIW (State Publishing Institute).

Haas, Stephen M., \& Laura Stafford. 2005. Maintenance behaviors in same-sex and marital relationships: A matched sample comparison. The Journal of Family Communication, 5, 43-60.

Kane, T. R., Suls, J., Tedeschi, J. T. (1977). Humour as a tool of social interaction. In: A. J. Chapman \& H. C. Foot (ed. ), It's a funny thing, humour (pp. 13-16). Oxford: Pergamon Press.

Kazimierczak, M., Plopa, M. (2006). Kwestionariusz Komunikacji Małżeńskiej (Communication in Marriage Questionnaire), 109-158. In: M. Plopa (ed.) Więzi w małżeństwie i rodzinie. Metody badań. Kraków: Oficyna Wydawnicza "Impuls” (Impuls Publishing House).

Kuipers, G. (2008). The sociology of humor. In W. Ruch (ed.), The Primer of Humor Research (pp. 361-398). Berlin, New York: Mouton de Gruyter

Kuiper, N. A., Martin, R. A., \& Olinger, L. J. (1993). Coping humour, stress, and cognitive appraisals. Canadian Journal of Behavioural Science, 25(1), 81-96.

Kurcz, I. (2000). Psychologia języka i komunikacji. Warszawa: Wydawnictwo Naukowe SCHOLAR (SCHOLAR Publishing House).

Long, D. L., Graesser, A. C. (1988). Wit and humor in discourse processing. Discourse Processes, 11(1), 35-60.

Martin, R. A., Puhlik-Doris, P., Larsen, G., Gray, J., \& Weir, K. (2003). Individual differences in uses of humor and their relation to psychological well-being: Development of the Humor Styles Questionnaire. Journal of Research in Personality, 37(1), 48-75.

Martineau, W. H. (1972). A model of the social functions of humor. In J. H. Goldstein \&P. E. McGhee (red.), The psychology of humor: Theoretical perspectives and empirical issues (pp. 101-125). New York: Academic Press.

Morreale et al. (2011). Komunikacja między ludźmi. Warszawa: Wydawnictwo PWN (PWN Publishing House).

Norrick, N. R. (1993). Conversational joking: Humor in everyday talk. Bloomington, In: Indiana University Press.

Plopa, M. (2008). Kwestionariusz Komunikacji Małżeńskiej (Communication in Marriage Questionnaire). In: Plopa, M (ed.), Więzi w małżeństwie i rodzinie. Metody badań. Kraków. Warszawa: Oficyna Wydawnicza Plus (Plus Publishing House).

Priest, R., F. Thein, M. (2003). Humor appreciation in marriage: Spousal similarity, assortative mating, and disaffection. Humor, $16,63-78$. 
Radomska, A., Filipek, M., Sobiecka, J. (2007). Roda A. Martina koncepcja stylów humoru i możliwości jej zastosowania w badaniach nad rozwojem. In: Rydz, E., Musiał, D. (ed.), Z zagadnień psychologii rozwoju człowieka. Vol. I (pp. 11-37). Lublin: Wydawnictwo Towarzystwa Naukowego KUL JPI (Publishing House of the Learned Society of the John Paul II Catholic University of Lublin).

Raskin, V. (1985). Semantic mechanisms of humor. Dordrecht: D. Reidel.

Raupach. Psycholinguistic Models of Production. (pp. 251-267). Norwood, NJ: Ablex

Ryś, M. (1999). Psychologia małżeństwa w zarysie. Warszawa: Centrum Metodyczne Pomocy Psychologiczno-Pedagogicznej Ministerstwa Edukacji Narodowej (Methodological Centre for Psychological and Pedagogical Assistance at the Ministry of National Education). Saroglou, V., Lacour, Ch. Demeure, M-E. (2010). Bad Humor, Bad Marriage: Humor Styles in Divorced and Married Couples. Europe's Journal of Psychology 3, 94-121.

Tannen, D. (1987), Conversational Style: Analyzing talk among friends. In: $\mathrm{H}$. Dechert, M. Trzebińska E. (1981). Stały i zmienny sposób definiowania relacji $\mathrm{z}$ partnerem w toku komunikacji interpersonalnej a niektóre właściwości reprezentacji poznawczych i efektywność komunikowania się. Unpublished doctoral dissertation, University of Warsaw, Warszawa.

Zalewska, S. (2008). Dialog i komunikacja w małżeństwie i rodzinie. In: Dąbrowa, E., Jankowska, D. (ed). Pedagogika dialogu. Dialog warunkiem rozwoju osobowego i społecznego. pp. 209-216. 